https://doi.org/10.3126/batuk.v6i1.32628

THE BATUK : A Peer Reviewed Journal of Interdisciplinary Studies

Vol. 6, Issue No.1, Jan 2020, Page: 55-62

ISSN 2392-4802

\title{
Ideological Essentialization of Afghan Women in Hosseini's A Thousand Splendid Suns
}

\author{
Binod Sapkota \\ Lecturer, Saraswati Multiple Campus, TU
}

\begin{abstract}
This article analyses the representation of women in Khaled Hoesseini's novel $A$ Thousand Splendid Suns (2003). This novel foregrounds the Afghan history in the aftermath of the fall of monarchy and the subsequent Russianinvasion, rise of Taliban and the arrival of the US after 9/11. All these events resulted in ethnic cleansing, hunger, mass exploitation, displacement and physical and psychological trauma to the common people especially the poor, women, and children. They brought eternal political instability to the ancient nation. The article uses the feminist lens of interpretation and concludes that the novel presents a graphical picture of Afghan women, their sufferings, their fight against the social and political patriarchy and biasness, their pain, human values and struggle for dignity.
\end{abstract}

Keywords: Representation, Exploitation, Ideology, Gender Roles, Sharia Law Critically acclaimed author bell Hooks defines feminism as "a movement to end sexism sexist exploitation, and oppression" (240). Feminists have always attempted to subvert the prevailing hierarchies of religion, caste and gender. These feminists objected the portrayal of women in negative terms. They challenged the existing sexist and patriarchal culture and values of the society. Critics like Gayatri Spivak, through their influential writings, tried to deconstruct the stereotypical images of third world women. Some western feminist depicted the 'third world' women as robbed of their agency. In this light, Housseini's major characters in the novel go against this portrayal and show through their long and persisting fight against the patriarchal society that they are not voiceless and if situation forced, they could retaliate. Hoesseini's present novel can be taken as feminist rendition of Afghan women.

Khaled Hosseini captivates his readers through an adherence to displaying the reality of gender roles in Afghanistan through Nana, Mariam, Fariba, Laila, Aziza, and other minor female characters, and enables the readers to understand the distress and turmoil that women must face on a daily basis in Afghanistan. While the women struggle for survival, war and political upheavals sweep Afghanistan right from the abolition of Monarchy. We are first introduced to Nana, the bitter mistress of a 
wealthy businessman, Jalil, and their harami, more politely known as an illegitimate child, Mariam. This character was strategically placed in the first chapter; not only for chronological purposes, but to begin the novel with a tone of feminist assertion and anger for longstanding pain and inequality the females have suffered. Nana grabs Mariam's wrists and through gritted teeth, said: "You are a clumsy little harami. This is my reward for everything I've endured. An heirloom-breaking, clumsy little harami." (4). At the age of five Mariam couldn't understand the anger and hatred in Nana's mind but later she regrets that, "A harami was an unwanted thing; that she, Mariam, was an illegitimate person who would never have legitimate claim to the things other people had, things such as love, family, home and acceptance" (4). That was because of Nana's personal dismay of being cast aside to live in a shack with her harami, Mariam that she is driven to hate Jalil and resent Mariam for her loyalty towards him. She expressed her anger as, "A man's heart is a wretched, wretched thing, Mariam. It isn't like a mother's womb. It won't bleed; it won't stretch to make room for you (27). Initially, one views Nana as a harsh mother, one is able to understand her reasoning through the later portrayal of Mariam and Laila at the hospital. With Nana's attitude, a comment is made on the Islamic way of dealing with the sin of adultery. Nana was a simple housemaid used by a powerful man and later discarded when his other three wives protest. She was lucky to not have been punished in a more severe way of stoning to death in PreRussian invasion of Afghanistan. In this respect, Jalil was a generous man. He did not, however, provide Nana with any aid in conceiving but built her a rat-hole, Kolba. She advises Mariam, "Like a compass needle that points north, a man's accusing finger always finds a woman." (7). Nana's suffering of giving birth without care can be representative of the suffering of thousands of women.

Hosseini contrasts Nana's emotions with the innocence of Mariam as a young girl. She admires her father, his family and his riches, even though she does not share in them. Jalil's occasional visits to Kolba are satisfying because she does not know anything else beyond reality. The fact that Mariam relishes her time spent with Jalil, even prays for his long life portrays that many women are born ignorant of reality. Mariam is kept ignorant of how carelessly Jalil regards her till she too is betrayed by him. Jalil is the representative of wealthy men who are more concerned with appearance and status than a child who is his own flesh and blood. He lives the greater part of his life disregarding his mistreatment of Mariam and lets her sleep on the doorsteps when she visited her house for the first time. It is the society's brutally negative outlook of haramis that Jalil acts in this manner. Nana is left powerless in the situation, just as women are essentially powerless in the society. Similarly, 
Mariam was rejected by both of her parents, Jalil was ashamed of her and Nana in her deep despair committed suicide, rejecting Mariam and leaving her to suffer from the cruel hands of the society.

The allowance of multiple wives in the novel is displayed through Jalil and Rasheed. In this society, it is acceptable for multiple women to be bound to one man. Jalil had three wives: Afsoon, Khadija, and Nargis and ten children in addition to Mariam. Rasheed married Mariam and then Laila, just for his sexual desires but defends himself on religious grounds. Upon the marriage of Rasheed and Laila, Mariam is scared and unsure. Mariam, at this point, holds deep contempt for Laila even though both were compelled by the circumstances though different. The sharing of one husband can cause great rivalry among women; however, they realize that without creating peace, they are even more powerless and miserable. Mariam's initial discontent for Laila and Rasheed's marriage draws attention to the demeaning practice.

Society's emphasis on the male dominance is displayed with Rasheed's treatment of Mariam's miscarriages. His mood changes dramatically, "With each disappointment (six other miscarriages), Rasheed had grown more remote and resentful. Now nothing she did please him" (98). He is irritable and enraged so Mariam dreaded his homecoming and felt that she has "failed him" and has become "nothing but a burden to him." As Rasheed's distaste for Mariam grows, military planes and bombs are heard overhead. She could see military planes heading north and east, and sudden plumes of smoke rising to the sky. The Tanks had broken into the premises and a fierce battle was going on there. The novel displays Rasheed's growing anger towards Mariam as communism infiltrated Afghanistan and President Daoud Khan was murdered during the coup of 1978. The Radio announces,

The era of aristocracy, nepotism, and inequality is over, fellow ham-watans. We have ended decades of tyranny. Power is now in the hands of the masses and freedom-loving people. A glorious new era in the history of our country is afoot. A new Afghanistan is born. (100)

Whenever the power balance shifts and a new power center emerges, general people have high hopes that the changed political environment would bring about a positive change in the life of commoners but in reality their hopes are only illusion.

Afghanistan saw numerous political upheavals and they all betrayed them.Rasheed forces Mariam to chew a "handful of pebbles" in order to make her understand how her cooking tastes. He clasped her jaw, forced her mouth open and then forced the pebbles into it. "Through the mouthful of grit and pebbles, Mariam mumbled a plea. 
Tears were leaking out of the corners of her eyes." (103) He leaves Mariam to spit out pebbles, blood and the fragments of two broken molars. It is this act of brutality that shows Rasheed's impatience at her (Mariam's) ignorance of politics but, more predominantly, his disgust in her inability to reproduce, her inability to replace his downed son. This concept is taken further when Laila gives birth to a daughter that Rasheed would rather not have existed. Rasheed doesn't call his daughter by the name, Aziza-a cherished one but, "It was always the baby, or, when he was really exasperated, that thing" (231). The exploitation of women in male dominated society of Afghanistan is further highlighted by the fact that once Laila gives birth to a son, Rasheed sheds some kindness on baby Zalmai, his cherished boy. Rasheed began to spend excessive amounts of money on Zalmai, not using any of the Aziza's old toys, diapers, though these were still serviceable. He spoiled Zalmai with gifts they can't afford, including a TV and VCR, both items forbidden by the Taliban but Rasheed procures them on the black market. In contrast, he had previously refused to even buy girl clothes for Aziza, Laila's first child. Shortly after these gifts for Zalmai, he suggests that Aziza go into the streets and beg to cover the debt he has on Zalmai's petty gifts. This cruel contrast enables one to understand the role of women in Afghanistan. Rasheed wishes that Aziza beg and take on the burden of his actions like the other girls there. The solution provided for the family's poverty (to send Aziza away) is evidence that she is the most expendable member of her family. Furnishing the example of male dominated society where girls are being treated unfair and unworthy for living. This irrational way of thinking causes one to pity Aziza and find fault in Rasheed. The Taliban laws of Shari'a provide Rasheed the opportunity to suppress and subjugate all the related characters like, Mariam, Laila and especially Aziza. Being females they all suffer first because of the Afghan politics, its political heads and then because of their personal lives under the dictatorship of Rasheed.

Rasheed serves as more than a symbolic character, representing the evil and oppression that Islamic law places on women. There is a comparison regarding the concerns of women between the Taliban and Communist rule. The communists paved the way for the women to get education and work in offices. The Taliban especially created an environment that made it unbearable for a woman to get education and function on her own. Rasheed happily compels his wives to wear burqas after their marriages. It is the evil that emanates from Rasheed, his joy in the restrictive laws enforced by the Taliban that made him an unfavorable character. He finds pleasure in listening to "Voice of Shari'a", a radio program for the long list of the punishments by Taliban to the culprits. Rasheed was not bothered by the Taliban 
because "All he had to do was grow a beard... and visit the mosque", two things which he already did. He regarded the Taliban with a forgiving, affectionate kind of bemusement, as one might regard an erratic cousin prone to unpredictable acts of hilarity and scandal. The Taliban laws had not changed his lifestyle. In his mind, the laws helped him by placing restrictions on his wives and the little power they had left. Rasheed had mockingly crushed Laila in asking, "What good are all your smarts to you now" is accurate in expressing that women in Afghanistan are helpless. Laila expressed her shock at forced house arrest of women doing nothing according to Taliban laws. Rasheed informed her that such practices were common in the rest of Afghanistan already. Mariam agreed with Rasheed for the first time because she and Laila were already under such control, so why should the rest of the women live differently? During this discussion, Mariam realized, in the eyes of the Taliban, being a communist and the leader of the dreaded KHAD made Najibullah only slightly more contemptible than a woman (272).

Fariba, Laila's mother, was introduced as a woman who was shockingly different from Rasheed's point of view because her husband, Hakim, treated her with respect and care. Fariba did not serve the role that a typical Afghan mother pursued. She was defiant and "ferocious" when angered. Hakim, also, lacked the normal role with his "delicate hands, almost like a woman's". This description enables us to see that Hakim was not a man of malice or violent discipline. Fariba took to lying in her bed on most days after their sons Ahmad and Noor went to fight against Russia. Her mother, who remained preoccupied in the thoughts of her son's, ignored Laila. She believed, "People shouldn't be allowed to have new children if they'd already given away all their love to their old ones. It wasn't fair" (117). Laila was responsible for completing chores and preparing meals that her mother seemed incapable of doing. One witnesses the disintegration of Fariba's strength as the days go on. After the death of her two sons she took to wearing only black, never leaving her bed. This loss transforms her into a ghost, who completely disregarded any duties, including being a mother to Laila. Although this woman possesses the ability to act on her own, she is crushed by the result of war. It is the war that costs her sons and, ultimately, her life and Hakim's too.

Death seems like the most probable option for an escape from the harmful invasions of the Soviet Union, the oppressive Taliban regime, or abusive husbands like Rasheed. In accordance with the Shari'a law, a woman must only leave her home when accompanied by a mahram, a male relative. The two central characters Mariam and Laila are women from completely different backgrounds and the fate and circumstances bring them together and they bravely and valiantly fight for their 
60I THE BATUK : A Peer Reviewed Journal of Interdisciplinary Studies $\quad$ Vol. 6 Issue No.1 Jan 2020 ISSN 2392-4802

survival and self-eastern against the common enemy Rasheed i.e. the patriarchy. These two ladies dared to resist the oppressive patriarchal principle together. They not only dared to run away from Rasheed in spite of the fact that their plan is sure to fail and ends in severe consequences but also decided to kill Rasheed. Mariam went against the traditional knowledge that taught her to suffer without any protest and killed Rushed and helped Laila escape from the atrocity of the bullying husband at the cost of her own life.

Laila and Mariam were unsuccessful in their first attempt at escaping from their miserable life with Rasheed, mainly because there was no male family member with them. With the return of Tariq in 2001, Laila was successful to escape from Afghanistan to Pakistan with her two children, but at the cost of Mariam. She had to stay in Kabul and face the consequences of killing Rasheed, who was responsible for their sufferings for years. While attacking Rasheed, Mariam recounts her miserable life with Rasheed as, "Mariam lost count of how many times the belt cracked, how many pleading words she cried out to Rasheed, how many times she circled around the incoherent tangle of teeth and fists and belt, ... "(338). She remembered ever act of tyranny imposed upon them and murdered because,

Had Mariam been certain that he would be satisfied with shooting only her (Mariam), that there was a chance he would spare Laila; she might have dropped the shovel. But in Rasheed's eyes she saw murder for them both. (340)

This continuous social construction of reality about women has very devastating impact on women's physical, social and psychological wellbeing. The sociopolitical and cultural exploitation was wrongly associated with fate. The two leading characters not only fight against the male domination, they resist against the social stereotyping of women. Although Mariam lost her life in her struggle, her fight against the society bore fruit. It resulted in Leila's happy family life back in Kabul after a short stay in Pakistan. Mariam's sacrifice provided Leila a sense of purpose in her life when Laila choses to devote her life for the greater good of the society in Kabul.

While in 'Walayat prison' for women guarded by the Taliban, she was listening to Naghma; Mariam remembered that a man always finds a woman to blame. She pleads guilty, explained that Rasheed will have killed them all if she had not struck him first but the Judges didn't believe her and she was sentenced to death saying 'they must follow the law of Allah'. (356). It was in the moments before Mariam's 
execution that she thought: "She was leaving it (the world) as a friend, a companion, a guardian. A mother. . This was a legitimate end to a life of illegitimate beginnings" (361). She felt happy to have become a "person of consequence," having loved people in her life. Just like the flimsy state of Afghanistan, one was not entirely safe under the house of a man like Rasheed. The message that is put forth is that the options are scarce for women in Afghanistan. The death of Rasheed brings temporarily relief that enables Laila to escape. Mariam's death offers a final relief. In relation to the country, there cannot be relief until the war ceases, one passes away, or one flees.

The last date recorded in the novel is April 2003, when Laila, Tariq, and the children re-turn back to Kabul, at Laila's request. Although Kabul is not developed, there have been improvements. The city is slowly being rebuilt from the rubble. Afghanistan was changing and the changes were mostly good, rebuilding and replanting was going on. "Laila spots flowers potted in the empty shells of old Mudjahideen rockets-rocket flowers, Kabuli's call them” (398). Hosseini chooses to have Laila's family return to Kabul to express solidarity with the country that is better than it was, and is moving towards the greater safety and choice.

After the Taliban are ousted the, "Buildings had been reduced to rubble, trees cut down, and streets mobbed by children begging. The Taliban was gone, but a majority of people were living in abject poverty." The orphanage, which represented a time of despair, in which Aziza was placed in 2001 for a time, is being renovated with the help of Laila and Tariq.

They have repainted both the exterior and the interior of the orphanage.

Tariq and Zaman have repaired all the roof leaks, patched the walls, replaced the windows, carpeted the rooms where the children sleep and play. This past winter, Laila bought a few beds for the children's sleeping quarters, pillows too, and proper wool blankets. She had cast iron stoves installed for the winter. (399)

They were recognized for their contribution in the orphanage, which symbolized the developments in Afghanistan. Laila's new pregnancy offers hope to the end of the book and the determination to name a female child after Mariam is a fitting tribute to her. The end of the novel encapsulates a hopeful moment for Laila's family and for Afghanistan. Although the novel is open to different interpretations, the most dominant theme is the social, mental and physical oppression of Afghan women from the patriarchal society and their fight against this oppression. 
The novel A thousand Splendid Suns is the study of women in the traditional Afghan family. The novel is scattered with memorable female characters who all are fighting against the all-pervasive patriarchal society. Anyone who seriously studies the people of the novel can understand the prevalent attitude of Afghan society towards women. They are regarded as subservient second classes citizens. This subservient condition of women is depicted as natural and it is reinforced through the persistent and biased patriarchal interpretation of the religion in the ideologically male dominated cultural construct.

In conclusion, we can say that the novel $A$ Thousand Splendid Suns describes the pathetic condition of Afghan women under the repressive regimes and religious fanatics. Everyday, Afghan women went through domestic violence and they were confined to the four walls of their house. The central characters' slow but patient fight shows the never say die attitude of Afghan women. The victory of Laila in the novel gives a very positive and realistic message to the females that their life is in their own hand and if you have desire and guts to fight injustice, you can emancipate yourself.

\section{Works Cited}

Azad, Farhad. 'Dialogue with Khaled Hosseini Afghan Magazine.' LemarAftaab, afghanmagazine.com 3, no. 4 (June 2004). http://www.afghan magazine.com/2004_06/profile/khosseini.shtml (accessed on October 20, 2019).

Hooks, Bell. (2000). Feminist Theory: From Margin to Center. NY: Pluto Press. Hosseini, Khaled. A Thousand Splendid Suns. London: Bloomsbury, 2007. Kakutani, Michiko. "A Woman's Lot in Kabul, Lower than a House Cat's." New York Times, May 29, 2007, sec. E, The Arts/Cultural Desk; Books of the Times.

Montrose, Louis. "The New Historicism." Redrawing the Boundaries: The Transformation of English and American Literary Studies. Eds. Stephen Greenblatt and Giles Gunn. NY: MLA, 1992:392-418.

Sadat, Mir Hekmatullah. "The Afghan Experience: An Exploratory Study of Societal Realities Through the Lenses of Afghan Diasporic Literary Works." PhD diss.,Claremont Graduate University and San Diego State University, 2006. 